\title{
Education Reform and Innovation for Regular Colleges International Service Trade Course
}

\author{
Zhengang An \\ Shenyang Aerospace University College of Economics and Management 110136
}

Keywords: International service trade; Team teaching; Educational reform and innovation

\begin{abstract}
With the deepening of international trade liberalization, international service trade has become a very important part of international trade. As an application-oriented college, to set the course of international service trade should focus on knowledge and availability. While teaching, teachers should introduce the frontier theory and latest updates of practical experiments and carry out discussion based on hot issues in China. In addition, we should combine the theoretical course of International Service Trade as well as practice to cultivate applied talents to serve the society.
\end{abstract}

\section{Introduction}

Concerning the first half of 2015, China's services trade over the same period rose 13. $3 \%$, becoming the highlight of the new economic growth which has vigorously promoted the development of trade in services and is beneficial to release the severe foreign trade pressure, promote domestic rules to dock with international standards as soon as possible, encourage domestic service sector to innovate and realize the transform from a manufacturing country to a service power. With the socio-economic development and the advancement of technology, there are emerging challenges for updating knowledge and cultivating talents. According to the Ministry of Education, it is easy for us to find out that application-oriented colleges will become the main mode of higher education. What's more, international trade is a highly practical professional while traditional education will barely cultivate talents who can adapt to the society. So, the rapid development of international trade make the teaching reform on international service trade very urgent.

\section{Positioning and Targets of International Service Trade}

Global service trade is a trade form for different countries to carry out financial services, tourism, transport and other services. Based on rapid development of the world economy, global service trade has become a important course under the environment that global service trade excelling over products trade. In traditional theories, teaching materials of product trade are main contents while service trade is its extension. Along with the deepening of global service trade, its relative courses will play an important role in international economic and trade course teaching.

The course setting of international service trade aims to help students master relative theories as well as policies of service industry development and service trade along with its problems to help them be familiar with global service trade policy and research direction. Based on this, students can reasonably carry out application in society. The teaching goal is to make students be equipped with comprehensively thinking ability and enable them to apply relative agreement and rules to solve realistic problems.

Same as international goods trade, the teaching content of international service trade can also be divided into theory policy and practice. At present, international service trade teaching mainly focuses on theoretical policy and rarely pays attention to practice. Colleges mainly give lectures in terms of the concept of service trade, service trade system, theory policy tools, current condition etc, and they seldom analyze service trade from a micro perspective. As a result, students will think this course is too theoretical and macro without practice training, thus it is not closely related to employment and they are not interested in it. However, this situation is derived from an objective 
reason because there are a series of departments such as international finance, international law and international taxes which is very professional and complicated. Global service trade has a set of regulation and process while some schools provide professional international finance, law and accounting course. Therefore, it is not realistic to talk about practice in class. However, as the cradle to cultivate application-oriented talents, we should combine theory and practice to make it easier for students to be adapted to schools. To serve enterprise should be the goal of running a school, so we have to start from a realistic perspective to explore an operable and teaching system to improve students' interest as well as consensus while all teachers and colleges should strive to achieve this goal.

\section{Causes for Global Service Trade Course Teaching Problems}

The System of Course Content Is Incomplete. International service trade is a new course and it remains to be developed. For example, there are few cases teaching us how to reduce trade barriers in terms of finance, insurance, telecommunications etc. What's more, hot topics like the form and features of outsourcing services, development trend etc are not deepened and even worse some contents lag behind of the time. Therefore, students cannot understand the serviceability of relevant theories, laws and they cannot effectively combine service trade and international trade with a comprehensive understanding.

Insufficient Recognition on Course and Students Lack Interest. International service trade does not have long teaching hours with few credits as well as lower requirements comparing to other professional courses. During the teaching process, both teachers and students will feel sluggish. In addition, some students do not have a clear understanding and they have a random attitude about learning this course. For example, while teaching the theory and policy of service trade, some of them cannot recognize its importance, holding the view that if they are not going to be engaged in the international trade field, it is useless to learn this course. As a result, they are not interested in it and cannot have efficient learning.

Lack of Systematic Practicality. Service trade is a very practical subject, but international service trade is in shortage of practical teaching comparing to other trade professions. During the teaching process, teachers constantly imbue students with basic knowledge and concepts rather than relative practice, which will lead to students' boredom of class. At present, professional experiments provided by the service trade course is sand-table teaching carried out based on the process of goods trade, which does not include law operation and practical training. As a result, there are not practical talents.

\section{Collaborative Teaching Method Trying}

Concerning those improper contents of international service trade, this author tries to suggest and implement a collaborative teaching method, showing as the following:

Introduce Elements Which Keep Pace with Times. International service trade as an emerging subject, its teaching contents should keep pace with times and change along with the time. Therefore, teachers should have a good understanding of the global trade activities to master relevant arguments and timely adjust teaching contents. What's more, teachers should add some points related to real economy and hot topic such as outsourcing international services, currency and futures markets. By introducing new knowledge, closely integrating with reality, the class will be lively and can bring the enthusiasm of students into play. In addition, the importance of this course should be promoted in other big occasions to let students take the initiative to understand the theory and carry out practice.

Adopt Collaborative Mode to Make Students the Main Subjects. During the teaching process, teachers are organizers to guide students to learn while students are main subjects. The mode made up by teachers and students as well as students and students should be set up to exchange views, which can stimulate students' aspiration to learn with a team and can deepen their understanding. In 
the process of implementing international service trade course, this author tries to adopt collaborative teaching mode and introduce interactive teaching.

Collaborative teaching method: assign work $\rightarrow$ discuss in groups $\rightarrow$ give a lecture with examples $\rightarrow$ conclude and improve. The combination of traditional teaching method and collaborative teaching method is advancement and supplementary for the current international service trade. In international service trade teaching, we should flexibly carry out an assistant teaching mode to firstly hold a meeting to discuss important points and divide students into different groups; secondly, we should clear assignment and rules to let students organize by themselves. Concerning some difficulties, teachers will give explanations. Afterwards, the teaching group should make courseware and discussion. At last, students will give report in the monthly meeting while teachers give comment to promote good deeds and help students.

Collaborative Teaching Mode Cases. In international service trade classes, single inculcation will make students feel bored and have negative emotions which will affect teaching quality. In order to effectively change this negative situation, we should carry out teaching collaborative mode to make students to take the initiative to participate in the case discussion and find out what make them interested in. However, this mode requires teachers to be familiar with the teaching contents to write cases and closely related ideas with structure. Sometime, they can also adopt proper topic to guide so as to let students to find out and apply knowledge. For example while talking about the chapter of international service trade freedom, teachers can adopt the successful case of Carrefour and PricewaterhouseCoopers in China to let students talk about the effect on domestic politics, economy and culture cased by the freedom of international service trade. What's more, teachers can also inform students of the teaching contents in advance via emails to let them have a brief understanding first. Furthermore, background knowledge as well as methods to check relevant cases should be provided to help them have the access to refer to, which will be beneficial to let them to better analyze the case. The practice proves that collaborative teaching mode is conducive to cultivate students' ability to independently learn and apply knowledge.

The teaching collaborative mode can be carried out in groups, which can be organized based on the education background, learning habits and learning subjective. In addition, a responsibility system with role change and rotation can be organized to demonstrate students' responsibility and ability. For example, while discussing about the chapter of international service trade, we choose A as the group leader in the learning group. While talking about another chapter we will take B as another group leader so as to avoid the circumstance of taking advantage of other people and guarantee that every student get the opportunity to show their abilities.

In addition, if there are different ideas especially when students talk about hot topics we can take this question as an example to let students and teachers discuss together and realize interaction. For example, while talking about transnational investment. We should adopt the case that service industry in India is attractive to help students learn the enlightenment and measures that India took to attract foreign capitals so as to make beneficial conclusions. Moreover, while taking about the chapter of international financial service trade, we should give both the successful and unsuccessful case of Korea and Portugal to let them compare and conclude. By the way, cases can be adopted to help students know the origin and development to on the one hand help students know more and on the other hand help them apply knowledge into reality.

Class Reform Innovation Gets Achievement. Based on course teaching for two years, the author learned about students' enthusiasm and initiative, independent learning, dialectic learning and applied learning. The effect of teaching reform and innovation shows firstly in terms of research ability improvement. Collaborative teaching requires students to refer to a series of materials to let students master the first original source and understand theoretical knowledge, participate in group discussion, make PPT and clear their ideas, which can improve their communication skill. Secondly, their analytical thinking ability is improved. In collaborative teaching, students will research and think independently, which can train their logical thinking ability. Thirdly, it will cultivate team spirit. Collaborative teaching is carried out based on groups while teachers carry out mutual work which is the key influencing the learning efficiency. Therefore, 
in the process of collecting materials and participating in discussion, they can experience the advantage of team spirit.

\section{Conclusion}

In the teaching process of international service trade, incomplete system, low recognition and practicability are common. In teaching reform, the author tries unremitting efforts to implement an innovative collaborative teaching method to stimulate students' learning interest and initiative which has gained achievement in improving students' ability to analyze and solve problems and can be referred to deepen the class innovation and reform.

\section{References}

[1] Liang Rui. Study on the combination of extra-curricular teaching and class teaching. China Electric Power Education, 2011(27).

[2] Yuan Yongyou. Discussion on independent international trade major expanding service trade. Foreign trade, 2011(12).

[3] TianYuan. The application of collaborative teaching mode in international service trade course. Economist, 2013(4).

[4] Tan Wenhua, Lifeng. A preliminary study on the cultivation mode of international economics and trade. Shandong Industrial Technology, 2013(14).

[5] Gu Hejun. Thoughts on the class case of international service trade [U] China Electric Power Education. 2009.(9):95-96.

[6] Sun Yaling. Practice and thoughts on the collaborative teaching mode of international service trade [U] Journal of Zhejiang Wanli University, 2ulu. 23(3): 97 1uu

[7] Ni Chuoyuan. Discuss on the application of inclusive education in international service trade [U] Economic \& Trade Update. 2 u11 (6): 267268. 